\title{
Interpersonal Metadiscourse Markers in the "Monash Life” Magazine
}

\author{
Ni Luh Putu Ayu Kezia Yasinta \\ English Department, Faculty of Arts, Udayana University \\ ${ }^{1}$ [kezia27.ky@gmail.com]
}

\begin{abstract}
Metadiscourse is a new concept of analyzing the discourse related to the relationship between the writer and reader. This can be the way of communicating used by writer to reader. Interpersonal metadiscourse markers are divided into two broad terms; they are interactive and interactional metadiscourse markers. The aims of this research are to identify and explain the interpersonal metadiscourse markers used in the "Monash Life" magazine. This magazine was chosen because it contains many articles in which the writers convey their opinions. The study used twenty two articles in the magazine. The note taking technique was used as the method of collecting the data. First, the articles were read intensively; second, the phrases or words categorized as the type of interpersonal metadiscourse markers were selected. The qualitative method was used to analyze the data. Every sentence or paragraph which contains the types of interpersonal metadiscourse markers were analyzed and classified. The theory of metadiscourse proposed by Hyland (2005) was used in this study. The result of the analysis shows that there were sixty one data that contain the interpersonal metadiscourse markers in the magazine. There were thirty four data found in the category of interactive metadiscourse markers, and twenty seven data in the category of interactional metadiscourse markers. It could be concluded that the use of interactive metadiscourse markers was more dominant than interactional metadiscourse markers in the Monash Life Magazine.
\end{abstract}

Keywords: Metadiscourse markers, interactive metadiscourse, interactional metadiscourse.

\begin{abstract}
Abstrak
Metadiscourse adalah konsep baru untuk menganalisa wacana terkait dengan hubungan antara penulis dan pembaca. Ini bisa menjadi cara berkomunikasi yang digunakan oleh penulis ke pembaca. Pemarka metadiscourse interpersonal dibagi menjadi dua istilah yang luas; yaitu metadiscourse interaktif dan interaksional. Tujuan dari penelitian ini adalah untuk mengidentifikasi dan menjelaskan pemarka metadiscourse interpersonal yang digunakan pada majalah "Monash Life". Majalah ini dipilih karena berisi banyak artikel dimana penulis menyampaikan pendapat mereka. Penelitian ini menggunakan dua puluh dua artikel di majalah tersebut. Teknik mencatat digunakan sebagai metode pengumpulan data. Pertama, artikel tersebut dibaca secara intensif; Kedua, ungkapan atau kata-kata yang dikategorikan sebagai jenis pemarka metadiscourse interpersonal dipilih. Metode kualitatif digunakan untuk menganalisis data. Setiap kalimat atau paragraf yang berisi jenis pemarka metadiscourse interpersonal dianalisis dan diklasifikasikan. Teori metadiscourse yang diajukan oleh Hyland (2005) digunakan dalam penelitian ini. Hasil analisis menunjukkan bahwa ada enam puluh satu data yang berisi pemarka metadiscourse interpersonal di majalah tersebut. Ada tiga puluh
\end{abstract}


empat data yang ditemukan dalam kategori pemarka metadiscourse interaktif, dan dua puluh tujuh data dalam kategori pemarka metadiscourse interaksional. Dapat disimpulkan bahwa penggunaan metadiscourse interaktif lebih dominan daripada pemarka metadiscourse interaktif pada majalah Monash Life.

Kata kunci: Pemarka metadiscourse, metadiscourse interaktif, metadiscourse interaksional.

\section{Background of the Study}

In analyzing a text, the theory commonly used is discourse analysis. According to Nordquist (2017), discourse analysis is a broad term for the study of the ways in which language is used in texts and contexts, or texts' surrounding and defining discourse. This is also called discourse studies. Discourse analysis was developed in the 1970s as a field of study (e.g., Halliday \& Hasan, 1976). Theoretical perspectives and approaches used in discourse analysis include the following: applied linguistics, conversation analysis, pragmatics, rhetoric, stylistics, text linguistics, and many others. Therefore, it is important to enhance our knowledge of the use of language in society.

The latest theory of discourse analysis is metadiscourse. Metadiscourse is a new concept in the field of discourse analysis that is related to the writer and reader. Language acts to present information through the organization of the text itself as well as engage the readers to understand it (Fuertes-Olivera et al., 2001). In analyzing a text, researchers may study metadiscourse elements based on their forms, meanings or functions among which functional studies have been more commonly used. (Gholami, Mehrnaz. Tajalli, Ghaffar.,. 2014)

According to Vande Kopple (1985) and Crismore (1993), metadiscourse markers are divided into two types: textual metadiscourse and interpersonal metadiscourse. Textual metadiscourse is responsible for creating some sort of integration and cohesion for the text created. Meanwhile, interpersonal metadiscourse helps writers interact with their readers. According to Hyland (2005; 50-52) metadiscourse has only two types; they are interactive metadiscourse and interactional metadiscourse.

This research focuses on analyzing the interpersonal metadiscourse marker in the magazine entitled Monash Life. This magazine was chosen because it contains many articles in which the writers convey their opinions. It is related to the topic of this research that is interpersonal metadiscourse marker.

\section{Problem of the Study}

a) What are the forms of interpersonal metadiscourse markers used in the articles of the magazine entitled Monash Life?

b) What are the functions of interpersonal metadiscourse markers in the articles of the magazine entitled Monash Life?

\section{Aims of the Study}

a) To identify the forms of interpersonal metadiscourse markers used in the articles of magazine entitled Monash Life.

b) To explain and analyze the functions of interpersonal metadiscourse markers used in the articles of magazine entitled Monash Life.

\section{Research Method}

This section has four parts; they are data source, method and technique of 
collecting data, method and technique of analyzing data, and method and technique of presenting analysis. This research is qualitative research, because the data are the interpersonal metadiscourse markers in the Monash Life magazine.

\subsection{Data Source}

The data in this study were taken from the English magazine entitled Monash Life published by Monash University Strategic Marketing and Communications in 2016 which has more than thirty articles. However, in this analysis, the data were selected from twenty two articles that convey the writer's opinion. It is related to the topic of interpersonal metadiscourse which means the relation between people and metadiscourse markers used to help engage the writer and reader.

\subsection{Method and Technique of Collecting Data}

The note taking technique was used as the method of collecting the data. The required data were collected from the magazine and the techniques used are as follows: First, the articles were read intensively; second, the phrases or words categorized as the types of interpersonal metadiscourse marker were selected.

\subsection{Method and Technique of Analyzing Data}

The qualitative method was used to analyze the data. Every sentence or paragraph which contains the types of interpersonal metadiscourse markers were analyzed and classified.

\subsection{Method and Technique of Presenting Analysis}

The informal method was used as the way of presenting the result of the data analysis. The data were explained and described through sentences. The procedures of analyzing the data are as follows: First, the data in the form of paragraph was presented; the phrase or word categorized as the interpersonal metadiscourse markers were bolded and underlined. Second, the discussion of the data from each category is presented descriptively in-depth in the form of tables.

\section{Result and Discussion}

The result and discussion of this analysis only show one each type of interpersonal metadiscourse markers found in the Monash Life magazine.

\subsection{Interactive Metadiscourse has five} features; they are code glosses, endophoric markers, evidentials, frame markers, transition markers.

\section{(1-1)}

Abo fronts 11 stories for the Monash campaign, which has, at its heart, a philosophy of challenging conventions with a spirit of interrogation so that we might have a bigger impact on the world. That is something Abo does, and as she found herself exploring faculties and spaces around the Clayton campus, it sparked memories of her own time at Monash when she completed an arts degree with a major in journalism, beginning in 2004. "It was like being a student again," she says.

(The seventh paragraphs of An Inquiring Mind)

The phrase so that is categorized as code glosses in interactive metadiscourse. It functions to give illustration to what might happen as the impact of the philosophy of the challenging conventions. It helps the reader understand the result of the previous discussion. 
"For example, our students are currently working on smart cities, regenerative medicine, solar cell energy systems and sustainability projects"

(The third to seventh paragraphs of Ahead of the Game)

The phrase for example is categorized as endophoric markers in interactive metadiscourse. It functions to direct the reader to the specific information to what the writer's intends. Here, the writer directs the reader to the information of the jobs done by the students.

What made her project so innovative, according to program director, Ian Wong, is that it can be easily extended into other areas, such as keeping track of the eating patterns of elderly relatives, or organizing dinner parties for friend with various dietary and alcoholic preferences.

(The tenth to twelfth paragraphs of The China Solution)

The phrase according to is categorized as evidential in interactive metadiscourse. It functions to support the opinion of the text that comes from the specific source. Here, it refers to Ian Wong as program director who explains about the innovation of the project by Cindy. This helps convince the reader about the topic.

In short, all the apparent paths to digital disruption have been trialled - and universities have participated in all these forms of trial. Yet no trial so far has accelerated in a way that produces the disruption to universities imagined by those who see "ancient institutions in their last days of decadence".

(The fifth to seventh paragraphs of The Effects of Digital Disruption on The Future of Universities sub-point in Education in the Age of Disruption)
The phrase in short is categorized as frame markers in interactive metadiscourse. It functions to label stages of the discourse into the final conclusion. In this article, in short guides the reader to the author's conclusion of all the apparent paths to digital disruption that have been trialled - and universities have participated in all these forms of trial.

\section{(1-5)}

Watch TV vision of Clarkson in the Hawtorn coach's box each week and you will see he only communicates with his players between quarters. Otherwise, he talks to his assistant coaches (or line coaches as they are known in the business) and they communicate the key messages back to the interchange bench.

(The twenty-third paragraphs of Mastermind)

The word otherwise is categorized as transition markers in interactive metadiscourse. The function is to indicate the other view point of the author to the reader. In this article, the author makes the reader see the other side of the coach.

5.2 Interactional Metadiscourse has five features; they are attitude markers, self-mention, engagement markers, hedges, boosters.

These three regulatory hurdles are neither minor nor easily dismissed or overcome. As a society we wish to be sure that our bridges and buildings will stand and be safe, that our health service will do no harm and hopefully cure, and so on.

(The third to sixth paragraphs of The Quality and Reputation of Higher Education Providers sub-point in Education in the Age of Disruption)

The word hopefully is categorized as an attitude marker in interactional metadiscourse. It functions to express the 
author's intended mood about the argument. The word hopefully in this article emphasizes the word cure.

Higher education and, indeed, universities will be the source of their own disruption. I do not expect it to be the end of venerable institutions, though I think the landscape will look different in 10 years. And $\mathbf{I}$ can make that prediction because the landscape looks very different now than 10 years ago.

(The third to sixth paragraphs of The Quality and Reputation of Higher Education Providers sub-point in Education in the Age of Disruption)

The word I is categorized as selfmention in interactional metadiscourse. It functions to directly express the involvement of the author in the argument. The following statement on the Data 43, the word I refers to Professor Margaret Gardner AO as the author of the argument.

How real is this future for universities? What evidence is there of disruption occurring on this scale? To answer this, we must consider two trends affecting universities.

(The seventh paragraphs of Education in the Age of Disruption)

The phrase we must is categorized as engagement marker in interactional metadiscourse. It functions to guide the reader's expectation as intended by the author. In this article, the phrase we must is used by the author that refers the readers together to the author to guide their expectation as what the author intended.

"If we sit still for even one minute we're going to be passed by," he declares. "So how do we modify ourselves to make us get even better?"

(The thirty-eight and thirty-ninth paragraphs of Mastermind)

The word if is categorized as hedges in interactional metadiscourse. It functions to show the author's viewpoint of something by giving some possibilities. In this article, the author tries to steer the reader's expectation by telling the possibility with the word choice if.

Managers must respond quickly as markets and organisations transform. Even when companies launch products and services in rapid succession, the next generation is ready to go. "In this context, the risk of managers and executives being hesitant are significant," he warns. "They must be able to think clearly, draw conclusions quickly, and act decisively.

(The third to seventh paragraphs of Ahead of the Game)

The word decisively is categorized as boosters in interactional metadiscourse. It functions to sway the reader and to create the unity with the audience. In this article, decisively shows the expression of the author to make the reader certain and agree with the discourse as is intended by the author.

\section{Conclusion}

Interpersonal metadiscourse marker is a new term of discourse analysis. It functions to help the writer express their intended messages toward the reader or the audience. Interpersonal metadiscourse markers are divided into two broad terms; they are interactive and interactional metadiscourse markers. Both of the markers also are divided into five elements; interactive metadiscourse which includes code glosses, endophoric 
markers, evidential, frame markers, and transition markers; and interactional metadiscouse are attitude markers, selfmention, engagement markers, hedges, and boosters.

This research analyzes the form and function of the interpersonal metadiscouse markers in the Monash Life magazine. The result of the analysis shows as follows:

\section{Interactive Metadiscourse}

a) Code Glosses: to supply information by rephrasing and illustrating.

The forms found in the data are as follow: such as, so that, as well as, called, while, in other words, typically, meanwhile, instead, Cindy explains

b) Endophoric Markers: to direct the reader to the information in the other parts of the text.

The forms found in the data are as follow: in this edition, for example, I outline earlier, for instance.

c) Evidential: to direct the reader to the information in the other text.

The forms found in the data are as follow: to quote, according to, Robinson says.

d) Frame Markers: to order the information in the text.

The forms found in the data are as follow: in short, and then, by the time, after, to address, on the other hand.

e) Transition Markers: to express the relation between the argument.

The forms found in the data are as follow: otherwise, yet, and, although, therefore, similarly, because, but, anyway.

\section{Interactional Metadiscourse}

a) Attitude Markers: To express the writer's attitude toward the argument.

The forms found in the data are as follow: I hope, we hope, unfortunately, hopefully, I would expect, I think, of course.

b) Self-Mention: To reference the writer explicitly.

The forms found in the data are as follows: I, we.

c) Engagement Marker: To build relationship between the reader and the writer in the text.

The forms found in the data are as follows: you, we must, we.

d) Hedges: To indicate the writer's viewpoint of possibilities.

The forms found in the data are as follows: if, so, though, might, perhaps.

e) Boosters: To express certainty instead of doubt.

The forms found in the data are as follows: decisively, indeed, exactly, she believes, certainly, definitely.

\section{References}

Crismore, A., Markkanen, R., \& Steffensen, M. S. 1993. "Metadiscourse in persuasive writing: A study of texts written by American and Finish university students". Written Communication, 10(1), pp. 39-71.

Dafouz, E. 2008. "The pragmatic role of textual and interpersonal metadiscourse markers in the construction and attainment of 


\begin{abstract}
persuasion: A cross-linguistic study of newspaper discourse". Journal of Pragmatics, 40, pp. 95113. doi: 10.1016/j.pragma.2007.10.003
\end{abstract}

Fuertes-Olivera, P. A., VelascoSacristan, M., Arribas-Bano, A., \& Samaniego-Fernandez, E. 2001. "Persuasion and Advertising English: Metadiscourse in Slogans and Headlines". Journal of Pragmatics, 33, pp. 1291-1307.

Gholami, Mehrnaz. Tajalli, Ghaffar.,. 2014. "An Investigation Of Metadiscourse Markers In English Medical Texts And Their Persian Translation Based On Hyland's Model", European Journal of English Language and Literature Studies. Volume 2, Nomor 2, pp. 114.

Hunbbel Meer, S. (2016). Four Different Types of Writing Styles: Expository, Descriptive, Persuasive, and Narrative [Internet]. Available from: https://letterpile.com/writing/FourTypes-of-Writing [Accessed $1^{\text {st }}$ January 2018]

Hyland, K. 2005. Metadiscourse: Exploring Interaction in Writing. London: Continuum.

Nordquist, Richard. (2017). Discourse Analysis, Observing the Use of Language [Internet]. Available from: https://www.thoughtco.com/discours e-analysis-or-da-1690462 [Accessed $20^{\text {th }}$ May 2017]

Vande Kopple, W. J. 1985. "Some

Explanatory Discourse on

Metadiscourse". College

Composition and Communication36, 82-93. 